\title{
THE ROLE OF THE CERVANTES INSTITUTE IN THE IMPLEMENTATION OF THE CULTURAL POLICY OF SPAIN SINCE THE ESTABLISHMENT OF DEMOCRACY AND BEYOND
}

\author{
Katerina Papaioannou \\ University of Patras, GREECE, papaioannou.kat@gmail.com
}

\begin{abstract}
The objective of the study is to highlight the action plan of Spain in order to further promote its cultural sector after the establishment of a democratic regime which followed Franco's death in 1975. Spain intended to prepare a comprehensive cultural plan with clear objectives and determine the means for achieving it. We focus on the decisive initiative of the establishment of the Cervantes Institute and discuss sectors of its action as well as how Spain expanded and exploited the strong potential of Cervantes Institute. Our aim is to investigate whether Spain, having started a new chapter in its political history, exploited the power of culture and implemented a new well-structured and active cultural strategy.

The Cervantes Institute was initially designed with an aim to map and accurately record the state of the Spanish language all over the world, to create access paths to native Spanish population in different countries and to connect with them gaining their alliance and support. The essence and work of the Cervantes Institute was certainly multidimensional and complex and was strongly based on the cultural strength of the Spanish language which formed an international, dynamic connection channel. However, there were several major organizational inefficiencies and drawbacks which the Cervantes Institute should overcome. After all, the successful implementation of the cultural policy incarnated by the Cervantes Institute was an important bet not only for the Institute but for the entire Spain, as well.

In this context, we present and analyze in detail how Spain designed and implemented a renovated cultural policy highlighting the crucial role of the Cervantes Institute and further discuss whether Spain eventually managed to achieve a leading role at an international level.
\end{abstract}

Keywords: Cultural policy, democratic Spain, Cervantes Institute.

\section{INTRODUCTION}

The arrival of democracy in Spain after Franco's death1 brought with it increased initiatives in the field of

\footnotetext{
1 Transition to democracy began shortly after Franco's death on November 20, 1975, while its completion is usually placed in the 1978 Spanish Constitution, the failed coup attempt on February 23, 1981, or the victory of the Spanish Socialist Workers Party in the parliamentary elections of October 28, 1982. This transition period is considered as the Spanish political changeover and is the period of the cotemporary history of Spain when democracy was restored.
} 
cultural action, although initially lacked a plan with the objectives to be achieved and the means that should be used to achieve them. The date when the Cervantes Institute (Instituto Cervantes (IC)) was established, 1991, was crucial for the organization and implementation of the Spanish cultural action. This memorandum was presented as a breach of an effort that was long pending and was eventually supported by references to the effect of other foreign institutions2 of similar nature. The establishment of the Cervantes Institute, which had been postponed for long, gained potential in the wake of action taken by Spain in 1992, when Spain undertook the organization of major international events. The 1992 Olympics were held in Barcelona, Spain, between July 25 and August 9, 1992. In addition, another important event organized by Spain in 1992 was the International Fair (known as «Expo '92»), which was held in Seville, capital of Andalusia. In this way, Spain wished to highlight the dynamic presence of the country abroad, as well as its commitment to follow the path of modernization, after the consolidation of a democratic political system in the country.

In this study, we investigate whether Spain, having now opened a new page in its political history, realized and exploited the power of culture as well as if Spain designed and implemented a new, organized and active cultural strategy. In this context, we present and analyze the decisive initiative of the creation of the Cervantes Institute, how Cervantes Institute acquired a particularly dynamic character as well as its activity areas.

\section{THE ACTION OF CERVANTES INSTITUTE IN A DEMOCRATIC SPAIN}

The arrival of democracy in Spain after Franco's death3 brought with it increased initiatives in the field of cultural action, although initially lacked a plan with the objectives to be achieved and the means that should be used to achieve them. The date when the Cervantes Institute (Instituto Cervantes (IC)) was established, 1991, was crucial for the organization and implementation of the Spanish cultural action. This memorandum was presented as a breach of an effort that was long pending and was eventually supported by references to the effect of other foreign institutions 4 of similar nature. The establishment of the Cervantes Institute, which had been postponed for long, gained potential in the wake of action taken by Spain in 1992, when Spain undertook the organization of major international events. The 1992 Olympics were held in Barcelona, Spain, between July 25 and August 9, 1992. In addition, another important event organized by Spain in 1992 was the International Fair (known as «Expo '92»), which was held in Seville, capital of Andalusia. In this way, Spain wished to highlight the dynamic presence of the country abroad, as well as its commitment to follow the path of modernization, after the consolidation of a democratic political system in the country.

This new Institute was responsible for responsible for promoting the study and the teaching of Spanish as a foreign language as well as for promoting the Spanish culture. To this end, Cervantes Institute was merged with a set of mechanisms previously existing under the auspices of various ministries (mainly the Ministry of Foreign Affairs). Following the reform of Spain, Cervantes Institute exploited these mechanisms as its antennas in the world. As a legacy of the previous regime, the new organization had a strong position in Europe and limited presence in the Middle East and North Africa which was further decreased in the US and other African and Asian countries (De Jevenois, 1996, p. 203-207).

However, Cervantes Institute still needed to overcome organizational problems and problems related to illtrained teachers, it needed to establish a standardized teaching system of the Spanish language which should be adopted by Cervantes Institute and also other co-operating centers, it should organize a process

Despite political and economic crises Spain went through, transition to democracy was among the factors which allowed Spain to join the EEC (1986) and NATO (1982) and contributed to political and social modernization.

${ }^{2}$ Foreign institutions with similar objectives and action included:

- Alliance Française, for details see: http://www.alliancefr.org/en/who-are-we

- Goethe Institut, for details see: http://www.dw.com/en/goethe-institut-looks-back-on-60-years-of-cultural-exchange/a15277312

- British Council, for details see: https://www.britishcouncil.gr/en/about

3 Transition to democracy began shortly after Franco's death on November 20, 1975, while its completion is usually placed in the 1978 Spanish Constitution, the failed coup attempt on February 23, 1981, or the victory of the Spanish Socialist Workers Party in the parliamentary elections of October 28, 1982. This transition period is considered as the Spanish political changeover and is the period of the cotemporary history of Spain when democracy was restored. Despite political and economic crises Spain went through, transition to democracy was among the factors which allowed

Spain to join the EEC (1986) and NATO (1982) and contributed to political and social modernization.

${ }^{4}$ Foreign institutions with similar objectives and action included:

- Alliance Française, for details see: http://www.alliancefr.org/en/who-are-we

- Goethe Institut, for details see: http://www.dw.com/en/goethe-institut-looks-back-on-60-years-of-cultural-exchange/a15277312

British Council, for details see: https://www.britishcouncil.gr/en/about 
for certifying knowledge of Spanish as a Foreign Language and also establish new libraries and documentation centers as well as a website 5 for the promotion of services offered thus introducing new technologies to serve its objectives. Cervantes Institute also worked on acquiring accurate knowledge on the state of the Spanish language around the world and reaching native Spanish population in different countries and enjoying their support. At the same time, Cervantes Institute developed a series of cultural activities, which aimed to introduce a form of programming, to exploit resources available to the Institute, to cooperate with other national and foreign Institutes and to develop appropriate and efficient communication strategies with them. The work of Cervantes Institute received a multidimensional character. It utilized a great asset, i.e., the Spanish language, an element of outstanding significance since it connected all nations of Latin America and struggled to improve the image of a country with low productivity and people mainly interested in having fun and enjoying the sun and the sea (Ybañe, Pascual, Castillo, Moreno, Otero, 1996, p. 52).

The establishment of democracy in Spain, economic growth and the search for an international leading role were reinforced by Spain joining the European Union. In this way, the reform of a faltering foreign cultural policy and the formulation of a new policy that would be based on cooperation were supported. Since Spain joined the EU, Europe has become the preferred area for cultural promotion, given that cooperation with Latin America had already been established. Other attractive areas were North Africa in the context of the Spanish Mediterranean policy, the Middle East, where Spain wished to receive a role by participating in talks and negotiations in order to contribute to the efforts for peace, as well as countries of the Asia-Pacific region where in addition to existing ties with Philippines, Spain had a strong objective to strengthen trade links in the region. Relations with the US were maintained mainly in the field of scientific and technological exchange; however, as in other areas, many cultural activities were developed for the promotion of Spanish culture. It is worth noting that despite the fact that the state had been traditionally considered as the main source of cultural activity, at that point there was a clear turn towards a more active participation of civil society in cultural activity.

During the end of the 20th century and especially during the first decade of the 21st century, cultural action outside Spain received significant attention and was highly promoted together with the promotion of the image of the country, which was successfully upraised by the presence, diversity and complexity of Spanish culture (Gómez-Escalonilla, Figueroa, 2012). The institutional framework became denser, with a network of public and private stakeholders and actors involved with higher or lower intensity in international cultural relations. Following a similar fashion, the range of action expanded to all continents for the development of extensive cooperation, which included areas increasingly enlarged. These areas extended from teaching and art to scientific exchanges, environmental issues and issues related to combating poverty, and were in accordance with the commitment assumed by Spain towards multilateral international organizations (GómezEscalonilla, Figueroa, 2008).

In Europe, training programs, inter-university cooperation, programs on various branches of art and relevant research were carried out. The presence of the Cervantes Institute was particularly intense in Europe and gradually expanded also in non-Hispanic America, Africa, Asia and the Middle East6. The Cervantes Institute continues to contribute to the advancement of the Spanish language and, more generally, of the Spanish culture to non-Spanish-speaking countries; Cervantes Institute also plays the role of a guarantor for agreements and cooperation agreements with other countries as well as with similar entities or organizations. The initial objectives of the Cervantes Institute7 have been broadened to include issues related to the recognition of the Diploma of Spanish as a Foreign Language through an international network of interconnected centers, the online sale of official publications, the establishment of Spanish translation prizes, and other agreements for participation in projects of the cultural industry, such as publication of classics of Spanish literature by individual publishers, implementation of radio and television programs in collaboration with companies of Latin American, promotion of films having received awards by the Academy of Cinema and Audiovisual Arts8, etc.

\footnotetext{
${ }^{5}$ In 1997 Cervantes Institute established the Cervantes Virtual Center (Centro Virtual Cervantes, CVC) which also has as objective to contribute to the advancement and spreading of Spanish language and culture.

${ }^{6}$ The Cervantes Institute operates 36 centers in Europe, 14 in America, 10 in Asia and 10 in the Middle East. See: http://www.cervantes.es/sobre_instituto_cervantes/direcciones_contacto/sedes_mundo.htm

7 The Cervantes Institute begins its existence having as objectives "to define and promote the country's image in the world, supporting economy and trade, and to contribute to building a world based on mutual understanding and common knowledge". For details, see Exposición de motivos, Ley 7/1991 de 21 de marzo.

${ }^{8}$ Since 1991, cinema, as a cultural activity, is the most common action program of the Cervantes Institute. This can be easily seen by visiting the official website of the Cervantes Cervantes in each country and observing cultural events organized annually. For example, see: http://atenas.cervantes.es/gr/culture_spanish/historical_cultural_activities_2005.
} 


\section{CONCLUDING REMARKS}

In conclusion, the action of the Cervantes Institute during its twenty years of operation has significantly altered the cultural landscape in Spain. Cervantes Institute has played a catalytic role in the promotion of the Spanish language and culture at an international level. What's more, actions and initiatives of the Cervantes Institute have been consistent and clear with a view to promoting a specific cultural policy. Based on its course of action so far, Cervantes Institute is highly expected to continue to actively serve the dissemination of Spanish culture. Spain can certainly count the Cervantes Institute as an important ally for the promotion of Spanish culture around the world.

\section{REFERENCE LIST}

De Jevenois, P. (1996). La Dirección General de Relaciones Culturales y Científicas 1946-1996, edit. Ministerio de Asuntos Exteriores, Madrid.

Fernández, L. S., Pérez, D. R., Comellas, J. L. y Andrés-Gallego J. (1991). Historia General de España y América, La época de Franco, Ed. Rialp, Madrid.

Gómez-Escalonilla, L. D., Figueroa, M. (2008). Los compromisos internacionales de España en materia de cultura, edit. Elcano Royal Institute of International and Strategic Studies, Madrid.

Martínez, E. M., Roth, J. O. (2012). El discreto encanto de la cultura: Nuevas estrategias para la proyección exterior de la cultura: un enfoque práctico, edit. Ariel, Barcelona.

Ybañez, E., Pascual, J. A., Castillo, A., Moreno, F., Otero, J. (1996). El peso de la lengua española en el mundo, edit. Universidad de Valladolid, Valladolid. 